\title{
Salinity Tolerance of Eggs of Buergeria japonica (Amphibia, Anura) Inhabiting Coastal Areas
}

AUTHOR(S):

Haramura, Takashi

\section{CITATION:}

Haramura, Takashi. Salinity Tolerance of Eggs of Buergeria japonica (Amphibia, Anura) Inhabiting Coastal Areas. Zoological Science 2007, 24(8): 820-823

ISSUE DATE:

2007-08

URL:

http://hdl.handle.net/2433/108570

RIGHT:

(c) 日本動物学会 / Zoological Society of Japan 


\title{
Salinity Tolerance of Eggs of Buergeria japonica (Amphibia, Anura) Inhabiting Coastal Areas
}

\author{
Takashi Haramura* \\ Department of Zoology, Graduate School of Science, Kyoto University, \\ Sakyo, Kyoto 606-8502, Japan
}

\begin{abstract}
Buergeria japonica is one of a few frogs that breed in coastal areas. To understand why this species can breed in coastal areas, I tested the salinity tolerance of eggs of $B$. japonica collected from a coastal area of Okinawa Island, Japan. All eggs hatched within four days after oviposition. At $0 \%$ salinity (control), over $94 \%$ of eggs hatched normally, and even at $1 \%$ o salinity over $85 \%$ of eggs hatched. Survival rate of eggs was low at 2, 3, and $4 \%$, and no eggs hatched at $5 \%$ o salinity. These results indicate that low salinity, close to pure water, is necessary for successful egg development, even for populations of $B$. japonica that breed in coastal areas. Future studies are necessary to examine whether females of $B$. japonica breeding in coastal areas select appropriate oviposition sites where the environmental salinity level is sufficiently low for eggs.
\end{abstract}

Key words: salinity tolerance, amphibian eggs, Buergeria japonica, coastal area, egg mortality

\section{INTRODUCTION}

Coastal areas are considered a risky habitat for amphibians because adults and tadpoles have poor osmoregulatory ability at high salinity levels (Boutilier et al., 1992). In particular, high salinity leads to high mortality of eggs (Duellman and Trueb, 1986), decreasing the probability of successful breeding and development (Beebee, 1985; Uchiyama et al., 1990a; Viertel, 1999). Accordingly, few amphibian species breed in coastal areas (Balinsky, 1981). Only a few frog species can inhabit coastal as well as inland areas. Buergeria japonica is a ground-dwelling rhacophorid frog distributed on most islands of the Ryukyu Archipelago of Japan and on Taiwan. In the breeding season, the frogs retreat to places such as the rocky banks of streams during the day and lay eggs at night. This species has been reported to lay eggs occasionally in the mouths of streams, no more than $100 \mathrm{~m}$ from the sea (Maeda and Matsui, 1989). Haramura (2004) reported that the salinity of oviposition sites in coastal populations of $B$. japonica on Okinawa Island is continuously $2 \%$ or less despite their exposure to the sea breeze. However, no information is available on the salinity tolerance of eggs of $B$. japonica. To fully understand the adaptation of $B$. japonica to the coastal environment, we must determine the upper salinity-tolerance limit of the eggs. In the present study, I experimentally tested the survival rate of eggs of $B$. japonica at several salinity levels.

\section{METHODS}

Experiments were conducted in September 2006, which is late in the breeding season of $B$. japonica. To obtain eggs, amplexed pairs found in the water or alongside streams were captured

\footnotetext{
* Corresponding author. Phone: +81-75-753-4076; Fax : +81-75-753-4113; E-mail: haramura@ethol.zool.kyoto-u.ac.jp
}

between 2100 and $2400 \mathrm{~h}$ in an area on the coast where a study on oviposition site selection by $B$. japonica has been underway (from the shoreline up to approximately $230 \mathrm{~m}$ inland; Okinawa Island, Japan; $\left.26^{\circ} 50^{\prime} \mathrm{N}, 128^{\circ} 17^{\prime} \mathrm{E}\right)$. Each pair was placed separately into a plastic cup and taken to the Yona Experimental Forest Research Station, University of the Ryukyus, approximately $6 \mathrm{~km}$ from the field study site. Females deposited egg masses by the morning after capture, and the salinity-tolerance experiment started within 8 hours of egg deposition. Eggs of $B$. japonica are small (1.2-1.4 mm diameter); average clutch size is approximately 450 , and no foam nest is constructed. Because a pilot experiment revealed that all eggs die at salinities greater than 5\% (Haramura, unpublished data), the present experiment was conducted at six salinity levels $(0 \% \circ=$ control, $1 \%, 2 \%, 3 \%$, $4 \%$, and $5 \%$ o). Salinity was adjusted with tap water and $\mathrm{NaCl}$ (control=0\%, no $\mathrm{NaCl} ; 1 \%$, $0.70 \mathrm{~g} \mathrm{NaCL} / 700 \mathrm{ml} ; 2 \%, 1.40 \mathrm{~g} / 700 \mathrm{ml} ; 3 \%$, $2.10 \mathrm{~g} / 700 \mathrm{ml} ; 4 \%$, $2.81 \mathrm{~g} / 700 \mathrm{ml} ; 5 \%$, $3.51 \mathrm{~g} / 700 \mathrm{ml})$. Before the experiment, tap water was left for a few days in an open container to evaporate chloride. The salinity of seawater in the study area is approximately $33 \%$.

The egg mass of each female was divided into six portions of 20 eggs each. Each portion was then selected randomly, placed in a plastic cup containing $700 \mathrm{ml}$ of water at one of the salinity levels, and left to develop at ambient temperature. Eggs were completely immersed in the solution. Room temperature was almost the same as the outside air temperature during the experiment because I kept windows open. The number of live and dead eggs, water temperature, and $\mathrm{pH}$ were recorded daily during the experiment. Water was renewed daily, and dead eggs were removed. Eggs were assumed to be dead when egg development stopped or the embryo was infected with fungus (Gosner and Black, 1957). Embryos were scored as alive if they completely escaped from their membrane. Any deformities in hatchling larvae were recorded. I maintained eggs in another cup with tap water to examine the rate of normal larval development. Five eggs were removed every six hours and fixed with formalin. The stages of larval development in tap water (0\% salinity level) followed the classification of Gosner (1960), and are shown in Table 1. Each experimental treatment was continued until all eggs either hatched or died. The trial at each salinity level was replicated six times, using six egg masses laid by six females. Immediately after the termination of each trial, embryos were 
Table 1. Larval development of Buergeria japonica in tap water (water temperature $27.4-31.5^{\circ} \mathrm{C}$ ). Development stage follows that described by Gosner (1960). Experiment started within 8 hours of egg deposition.

\begin{tabular}{ccccccccccccccccccccc}
\hline Time after fertilization & Start & $6 \mathrm{~h}$ & $12 \mathrm{~h}$ & $18 \mathrm{~h}$ & $24 \mathrm{~h}$ & $30 \mathrm{~h}$ & $36 \mathrm{~h}$ & $42 \mathrm{~h}$ & $48 \mathrm{~h}$ & $54 \mathrm{~h}$ & $60 \mathrm{~h}$ & $66 \mathrm{~h}$ & $72 \mathrm{~h}$ & $84 \mathrm{~h}$ & $96 \mathrm{~h}$ & $108 \mathrm{~h}$ & $120 \mathrm{~h}$ & $132 \mathrm{~h}$ & $144 \mathrm{~h}$ \\
\hline Gosner stage & $8-9$ & 12 & $15-16$ & 18 & 19 & 20 & $20-21$ & $21-22$ & $21-22$ & 22 & $22-23$ & $22-23$ & 23 & $23-24$ & 24 & $24-25$ & 25 & 25 & 25 \\
\hline
\end{tabular}

released at the sites where their parents were collected. I used a total of 720 eggs in the experiment.

The Friedman test was used to compare the survival rate of eggs among salinity levels, water temperatures, and $\mathrm{pH}$ levels during the first two days of the experiment. The egg survival rate was compared across treatments for the entire duration of the experimnet. Because of small sample sizes due to the death of eggs in later days of the experiment, water temperature and $\mathrm{pH}$ were examined only for the first two days. To examine where differences resided among salinity levels, I performed Steel-Dwass post-hoc tests.

\section{RESULTS}

The overall ranges of experimental water temperature and $\mathrm{pH}$ were $27.2^{\circ} \mathrm{C}-28.7^{\circ} \mathrm{C}$ and $8.1-8.9$, respectively. There was no significant difference in water temperature

Table 2. Mean $\pm \mathrm{SE}$ of water temperature (WT) and $\mathrm{pH}$ at six salinity levels ( $0 \%_{\circ}-5 \%$ ) throughout the experiment. Figures in parentheses indicate sample size.

\begin{tabular}{|c|c|c|c|c|c|c|}
\hline \multirow{2}{*}{ Salinity level } & & \multicolumn{5}{|c|}{ Exposed day } \\
\hline & & Start & 1 day & 2 day & 3 day & 4 day \\
\hline \multirow[t]{2}{*}{ 0\%॰ (control) } & WT & $28.0 \pm 0.1$ & $27.5 \pm 0.1^{\text {acd }}$ & $27.8 \pm 0.1$ & $28.3 \pm 0.1$ & 28.3 \\
\hline & $\mathrm{pH}$ & $\begin{array}{l}8.5 \pm 0.04^{e} \\
(6)\end{array}$ & $\begin{array}{c}8.7 \pm 0.1 \\
(6)\end{array}$ & $\begin{array}{c}8.8 \pm 0.1 \\
(6)\end{array}$ & $\begin{array}{c}8.5 \pm 0.04 \\
(6)\end{array}$ & $\begin{array}{l}8.8 \\
(1)\end{array}$ \\
\hline \multirow[t]{2}{*}{$1 \%$} & WT & $27.9 \pm 0.03$ & $27.4 \pm 0.1^{\mathrm{ab}}$ & $27.7 \pm 0.1$ & $28.2 \pm 0.1$ & - \\
\hline & $\mathrm{pH}$ & $\begin{array}{l}8.4 \pm 0.03^{\text {efghi }} \\
(6)\end{array}$ & $\begin{array}{l}8.4 \pm 0.02^{\mathrm{jkl}} \\
(6)\end{array}$ & $\begin{array}{c}8.4 \pm 0.05 \\
(6)\end{array}$ & $\begin{array}{c}8.3 \pm 0.03 \\
(6)\end{array}$ & - \\
\hline \multirow[t]{2}{*}{$2 \%$} & WT & $27.9 \pm 0.03$ & $27.4 \pm 0.1^{\mathrm{ab}}$ & $27.7 \pm 0.1$ & $28.2 \pm 0.1$ & - \\
\hline & $\mathrm{pH}$ & $\begin{array}{c}8.3 \pm 0.02^{f} \\
(6)\end{array}$ & $\begin{array}{l}8.4 \pm 0.03^{\mathrm{mno}} \\
(6)\end{array}$ & $\begin{array}{c}8.3 \pm 0.03 \\
(6)\end{array}$ & $\begin{array}{c}8.4 \pm 0.1 \\
\text { (3) }\end{array}$ & - \\
\hline \multirow[t]{2}{*}{$3 \%$} & WT & $27.9 \pm 0.04$ & $27.4 \pm 0.1^{c}$ & $27.9 \pm 0.2$ & 28.3 & - \\
\hline & $\mathrm{pH}$ & $\begin{array}{l}8.3 \pm 0.01^{9} \\
(6)\end{array}$ & $\begin{array}{l}8.3 \pm 0.01^{\mathrm{jm}} \\
(6)\end{array}$ & $\begin{array}{c}8.4 \pm 0.1 \\
\text { (3) }\end{array}$ & $\begin{array}{l}8.3 \\
(1)\end{array}$ & - \\
\hline \multirow[t]{2}{*}{$4 \%$} & WT & $27.9 \pm 0.04$ & $27.4 \pm 0.1^{c}$ & $27.9 \pm 0.1$ & 28.2 & - \\
\hline & $\mathrm{pH}$ & $\begin{array}{l}8.3 \pm 0.04^{h} \\
(6)\end{array}$ & $\begin{array}{l}8.3 \pm 0.02^{\mathrm{kn}} \\
(6)\end{array}$ & $\begin{array}{c}8.3 \pm 0.1 \\
\text { (3) }\end{array}$ & $\begin{array}{l}8.3 \\
(1)\end{array}$ & - \\
\hline \multirow[t]{2}{*}{$5 \%$} & WT & $28.1 \pm 0.1$ & $27.5 \pm 0.1^{d}$ & 28.2 & 28.5 & - \\
\hline & $\mathrm{pH}$ & $\begin{array}{c}8.3 \pm 0.02^{i} \\
(6)\end{array}$ & $\begin{array}{c}8.3 \pm 0.02^{10} \\
(6)\end{array}$ & $\begin{array}{l}8.5 \\
(1)\end{array}$ & $\begin{array}{l}8.5 \\
(1)\end{array}$ & - \\
\hline
\end{tabular}

The same letter indicates not significant by post hoc test (Steel-Dwass) at the 0.05 level.

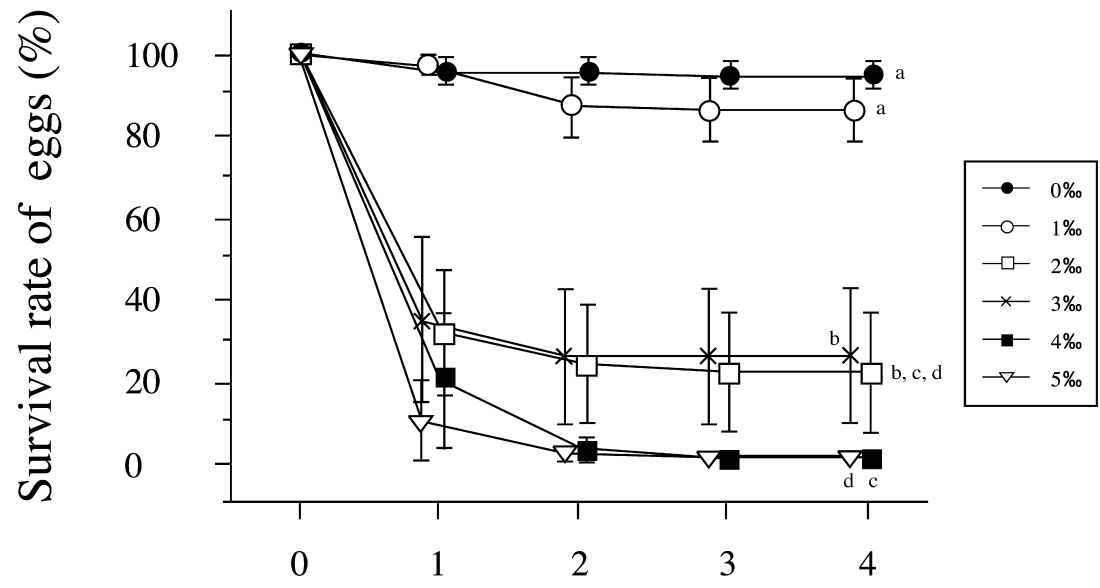

Exposed day

Fig. 1. Effects of salt exposure time on egg survival rates. Six replicates of twenty eggs each were placed in each salinity level (0-5\%) at the start of experiment. Means \pm SE are shown. The same letter indicates not significant by post-hoc test (Steel-Dwass) at the 0.05 level. 
among the six salinity levels on the starting day (Friedman test, $\left.d f=5, \chi^{2}=10.64, P>0.05\right)$, but there were significant differences 1 day after (Friedman test, $d f=5, \chi^{2}=13.31$, $P<0.05)$. There were significant differences in $\mathrm{pH}$ among the six salinity levels on both the starting day and 1 day after (Friedman test; starting day, $d f=5, \chi^{2}=15.33, P<0.01$; one day after, $d f=5, \chi^{2}=18.45, P<0.01$; Table 2). Approximately $94 \%$ of eggs at $0 \%$ salinity (control) developed and hatched by the fourth day; at $1 \%$ salinity, approximately $85 \%$ of eggs hatched. At $2 \%$ and $3 \%$ salinity, the hatching rate of eggs was lower than $30 \%$. At 5\% salinity, no eggs developed to hatching. At $0 \%$ salinity, hatching was observed on the second day (48 h) after fertilization. Salinity level significantly affected egg survival, which was high at $0 \%$ and $1 \%$ o salinity and low at $4 \%$ and $5 \%$ (Friedman test, $d f=5, \chi^{2}=21.05$, $P<0.001$; see Fig. 1). Deformities in hatchling larvae were observed at elevated salinities (1\%o, one hatchling; $2 \%$, two; $3 \%$, one), but no deformities were observed at $0 \%$.

\section{DISCUSSION}

Because few amphibian species breed in coastal areas (Balinsky, 1981), there have been few studies on the survival rate of amphibian eggs under saline conditions. The amphibian species most intensively studied with regard to egg development in saline conditions is the crab-eating frog (Rana cancrivora), which lives in brackish water such as mangrove swamps. Adults and tadpoles of $R$. cancrivora have a wide range of salinity tolerance, from freshwater to $80 \%$ seawater (26.4\%。 salinity; Gordon et al., 1961 ; Gordon and Tucker, 1965, 1968), but eggs fail to develop even in $10 \%$ seawater (approximately 3.3\%o; Uchiyama et al., 1990a). In Bufo calamita, which sometimes lives in areas frequently inundated with seawater, Beebee (1985) reported that eggs are killed by $15-20 \%$ seawater (approximately 4.95-6.6\% salinity). The present study showed that most eggs of $B$. japonica survived and hatched at $1 \%$ o salinity. However, most eggs failed to hatch at 2 and $3 \%$, and all eggs died at $5 \%$. These results indicate that low salinity, close to pure water, is necessary for successful egg development, even though the population of $B$. japonica studied here breeds in a coastal area.

Low $\mathrm{pH}$ in ambient water (approximately $\mathrm{pH}$ 3.6-4.6) also interrupts the embryonic development of eggs (Gosner and Black, 1957; Dunson and Connell, 1982; Freda and Dunson, 1985; Tyler-Jones et al., 1989; Beattie et al., 1992; Picker et al., 1993). Although $\mathrm{pH}$ values measured on the starting day and 1 day after were different among salinity levels, there were no low values ( $\mathrm{pH}$ 8.1-8.9). Therefore, the differences in egg mortality among salinity levels could not be attributed to differences in $\mathrm{pH}$. Differences in $\mathrm{pH}$ among the experimental treatments may simply have been caused by the differences in salinity. Water temperature 1 day after showed significant differences among the experimental treatments; the water temperature at $0 \%$ and 5\%。 salinity was approximately $0.1^{\circ} \mathrm{C}$ higher than that at other salinity levels (see Table 2). The cups containing the $0 \%$ and $5 \%$ salinity treatments were positioned in the outmost rows of cups, and their slightly higher water temperature may have been caused by this positional difference. At $0 \%$ salinity (=control), more than $94 \%$ of eggs hatched by the fourth day, and there were no hatching failures or deformi- ties in the hatchling larvae. Deformities in hatching larvae were observed in the salinity treatments. This was likely the result of elevated salinity; deformities in hatching larvae due to elevated salinity have been reported in other studies (Gordon and Tucker, 1965; Bebee, 1985).

The low salinity tolerance of amphibian eggs may induce deliberate oviposition behavior by females that breed in coastal areas. There has been no study concerning the oviposition behavior of amphibians inhabiting coastal areas; therefore, it is unknown how these females avoid high salinity for the successful development of their eggs. According to my research on $B$. japonica inhabiting a coastal area, Okinawa, Japan, the salinity at coastal oviposition sites is $2 \%$ or less (Haramura, 2004). Females move from a broad area upstream to a stream mouth and lay eggs in several masses (Haramura, 2005). In addition, an experiment on oviposition site selection showed that females are able to distinguish salinity levels in order to avoid high salinity for egg laying sites, by discriminating salinity levels higher than 2\%。 (Haramura, submitted data). Several studies have shown salinity tolerance for adult frogs (Gordon et al., 1961; Gordon, 1962; Schmidt-Nielsen and Lee, 1962; Uchiyama et al., 1990b). It is unknown how well adult $B$. japonica are able to tolerate high salinity, but at my field study site, both males and females were observed to remain and court in high-salinity areas influenced by saltwater ripples at high tide. I hypothesize that females of $B$. japonica breeding in coastal areas select appropriate oviposition sites where the salinity is low enough for eggs to develop successfully. More information is needed on oviposition behavior to understand amphibian adaptations to coastal environments.

\section{ACKNOWLEDGMENTS}

I thank S. P. Cook for editing the English; $\mathrm{H}$. Ota, who provided an instrument for measuring salinity; A. Mori for his valuable comments and suggestions on the manuscript; and two anonymous reviewers for comments. This work was supported in part by a grant for Biodiversity Research from the 21st Century COE, Kyoto University (A14), and was also supported by a Sasakawa Scientific Research Grant from the Japan Science Society.

\section{REFERENCES}

Balinsky JB (1981) Adaptation of nitrogen metabolism to hypertonic environment in Amphibia. J Exp Zool 215: 335-350

Beattie RC, Tyler-Jones R, Baxter MJ (1992) The effects of pH, aluminium concentration and temperature on the embryonic development of the European common frog, Rana temporaria. J Zool 228: $557-570$

Bebee TJC (1985) Salt tolerances of natterjack toad (Bufo calamita) eggs and larvae from coastal and inland populations in Britain. Herpetol J 1: 14-16

Boutilier RG, Stiffler DF, Toews DP (1992) Exchange of respiratory gases, ions, and water in amphibians and aquatic amphibians. In "Environmental Physiology of the Amphibians" Ed by ME Feder, Burggren WW, University of Chicago Press, Chicago, IL, pp 81-124

Duellman WE, Trueb L (1986) Biology of Amphibians. McGraw-Hill, New York, USA

Dunson WA, Connell J (1982) Specific inhibition of hatching in amphibian embryos by low $\mathrm{pH}$. J Herpetol 16: 314-316

Freda J, Dunson WA (1985) The influence of external cation concentration on the hatching of amphibian embryos in water of low pH. Can J Zool 63: 2649-2656 
Gordon MS (1962) Osmotic regulation in the green toad (Bufo viridis). J Exp Biol 39: 261-270

Gordon MS, Tucker VA (1965) Osmotic regulation in the tadpoles of the crab-eating frog (Rana cancrivora). J Exp Biol 42: 437-445

Gordon MS, Tucker VA (1968) Further observations on the physiology of salinity adaptation in the crab-eating frog (Rana cancrivora). J Exp Biol 49: 185-193

Gordon MS, Schmidt-Nielsen K, Kelly HM (1961) Osmotic regulation in the crab-eating frog (Rana cancrivora). J Exp Biol 38: 659678

Gosner KL, Black IH (1957) The effects of acidity on the development and hatching on New Jersey frogs. Ecology 38: 256-262

Gosner KL (1960) A simplified table for staging anuran embryos and larvae with notes on identification. Herpetologica 16: 183-190

Haramura T (2004) Salinity and other abiotic characteristics of oviposition sites of the rhacophorid frog, Buergeria japonica, in coastal habitat. Cur Herpetol 23: 81-84

Haramura T (2005) Buergeria japonica. Oviposition behavior. Herpetol Rev 36: 429-430

Maeda N, Matsui M (1989) Frogs and toads of Japan. Bun-Ichi Sogo Shuppan, Tokyo, Japan (in Japanese)
Picker MD, McKenzie CJ, Fielding P (1993) Embryonic tolerance of Xenopus (Anura) to acidic blackwater. Copeia 1993: 10721081

Schmidt-Nielsen K, Lee P (1962) Kidney function in the crab-eating frog (Rana cancrivora). J Exp Biol 39: 167-177

Tyler-Jones R, Beattie RC, Aston RJ (1989) The effects of acid water and aluminium on the embryonic development of the common frog, Rana temporaria. J Zool 219: 355-372

Uchiyama M, Murakami T, Yoshizawa H (1990a) Notes on the development of the crab-eating frog, Rana cancrivora. Zool Sci 7: 73-78

Uchiyama M, Ogasawara T, Hirano T, Kikuyama S, Sakayama Y (1990b) Serum and urine osmolyte concentrations during acclimation to various dilutions of seawater in the crab-eating frog Rana cancrivora. Zool Sci 7: 967-971

Viertel B (1999) Salt tolerance of Rana temporaria: spawning site selection and survival during embryonic development (Amphibia, Anura). Amphibia-Reptilia 20: 161-171

(Received January 23, 2007 / Accepted March 1, 2007) 